\title{
Landfill mining from extractive waste facilities: the importance of a correct site characterization and evaluation of the potentialities. A case study from Italy.
}

\author{
Giovanna Antonella Dino ${ }^{1 *}$, Piergiorgio Rossetti ${ }^{1}$, Luigi Perotti ${ }^{1}$, Walter Alberto ${ }^{2}$, \\ Heikki Sarkka $^{3}$, Frédéric Coulon ${ }^{4}$, Stuart Wagland ${ }^{4}$, Zoe Griffiths ${ }^{4}$, Franco Rodeghiero ${ }^{5}$
}

${ }^{1}$ Università degli Studi di Torino, Dept. of Earth Sciences, Via Valperga Caluso, 35, 10125, Torino, Italy

${ }^{2}$ IMAGEO srl. Via Valperga Caluso, 35, 10125, Torino, Italy

${ }^{3}$ South-Eastern Finland University of Applied Sciences, Patteristonkatu 3 D, 50100 Mikkeli, Finland

${ }^{4}$ Cranfield University, School of Water, Energy and Environment, Cranfield, MK43 0AL, UK

${ }^{5}$ Università degli Studi di Milano Bicocca, Dept. of Earth and Environmental Sciences, Piazza della Scienza, 4, 20126 Milano, Italy

*corresponding author: giovanna.dino@unito.it

\begin{abstract}
At present, little information is available on the opportunities and challenges to recover valuable critical raw materials (CRM) and secondary raw materials (SRM) from extractive waste (EW) deposits. In this study, an integrated framework describing the key steps required to assess the viability of CRM recovery from EW deposits is presented. The framework has been tested and validated using a pilot site located in the Northern region of Lombardy, Gorno. A tiered characterisation approach was used to support the framework and obtain information on (i) the deposit features and their characteristics including geocharacterisation of the waste layers, (ii) the physicochemical properties of the waste layers, and (iii) the presence of CRM/SRM hot spots using a combination of drone technology and geographic information system (GIS) data collection.

Zinc (0.65 to $19.3 \mathrm{wt} \%)$ and Cadmium (22 - $544 \mathrm{ppm})$ and to a lower extent Gallium (6.0 - 88.6 ppm) were the most abundant elements that could be potentially recovered from the waste rocks. Assuming that all $\mathrm{Zn}, \mathrm{Cd}$ and $\mathrm{Ga}$ were from exploitable minerals (eg. sphalerite, calamine, etc...), there are good opportunity of significant revenues ranging between 13.4 and $63 \mathrm{M} €$ for $\mathrm{Zn}, 18.5$ and $88 \mathrm{k} €$ for $\mathrm{Cd}$ and 132 and $530 \mathrm{k} €$ for Ga. While caution is needed in extrapolating these potential revenues, there are promising and supporting the potential economic viability of landfill mining at EW deposits.
\end{abstract}

Keywords: critical raw materials, secondary raw materials, extractive waste deposits, landfill mining, circular economy, zinc mine 


\section{Introduction}

Raw materials (RM) and critical raw materials (CRM; EC, 2017) supply is essential to both the maintenance and development of the EU economy as its industries rely on a steady RM supply. Thus, securing a sustainable RM and CRM supply and their circular use in the economy is of importance at EU level and beyond (Blengini et al., 2017; Coulomb et al., 2015; Vidal-Legaz et al., 2016). Furthermore, the developments of clean technologies coupled with economic growth exacerbate the short and long-term demand and needs (Blagoeva et al., 2016; Pavel and Tzimas, 2016). For example, Habib and Wenzel (2014) reported that the necessary supply $\mathrm{Nd}$ and Dy will grow from $10.0 \mathrm{Gg}$ to $54.5 \mathrm{Gg}$ and $0.5 \mathrm{Gg}$ to $4.95 \mathrm{Gg}$ respectively from 2010 to 2050 .

The mining sector is particularly prominent in the exploitation of natural resources, with large amounts of waste produced in connection with this activity. The estimated amount of waste produced in 2014 was in excess of $703 \times 10^{6}$ tonnes including waste rocks, residual waste from operation activities and tailings (Eurostat, 2017). The extractive wastes (EW) are composed of three main categories including (1) waste rocks: valueless rock that must be fractured and removed in order to gain access to or upgrade ore; (2) operating residues: waste arising from a primary selection to separate the material with a potential grade to be processed from the one, still enriched, but with no adequate grade; and (3) tailings: the fines residue coming from ore processing (BRGM, 2001). While reuse opportunities of EW are still limited to date, there is an opportunity for a combined resource recovery and remediation which will drastically reduce future remediation cost, reclaim valuable spaces, and at the same time unlocking billions of tonnes of CRM/SRM within EW deposits. Extractive waste are often composed of mono-waste material, similar to minerals and elements present in the ore deposit. Several studies are currently underway to investigate the presence and recovery of CRM and SRM from EW facilities (EC, 2017), in particular for the exploitation of:

- $\quad$ CRM (EC, 2017): REEs enrichments, for instance, have been recently documented in specific fractions related to processing of granite waste in Montorfano Area, Northern Italy (Dino et al. 2018); Platinum Group Elements (PGE) can be associated to waste connected with Ni sulphide mining (eg. Campello Monti, Northern Italy; Rossetti et al., 2017), and commodities such as $\mathrm{Ga}, \mathrm{Ge}$, In, fluorite and baryte may be present in waste related to $\mathrm{Zn}-\mathrm{Pb}$ exploitation (eg. Gorno mining area, object of the present paper);

- SRM such as:

- metals: eg. the average $\mathrm{Cu}$ still present in tailings coming from mining exploitation in the US has been estimated in $0.12 \%$ of the total amount $\left(12.9 \times 10^{6} \mathrm{kt}\right.$ of tailings containing $15.3 \times 10^{3} \mathrm{kt}$ of copper; Gordon, 2002). Moreover, Finnvedenlz et al. (1995) showed that the typical amount of $\mathrm{Cu}$ left in mine tailings from copper ore in Finland was in the range $2-10 \%$ of the produced $\mathrm{Cu}$, and the corresponding amount for $\mathrm{Zn}$ was in the range $5-70 \%$ (Edraki et al., 2014). Other samples are connected to a recent study of Campello Monti Ni mining area (Piemonte Region, Northern Italy), showing that the waste rock materials are characterized by up to $0.5 \mathrm{wt} \% \mathrm{Ni}, 0.1 \mathrm{wt} \% \mathrm{Cu}$ and 0.02 $\mathrm{wt} \% \mathrm{Co}$, and some operating residues are characterized by even higher metals enrichments: up to $2.4 \mathrm{wt} \% \mathrm{Ni}, 0.9 \mathrm{wt} \% \mathrm{Cu}$ and $0.1 \mathrm{wt} \% \mathrm{Co}$ (Rossetti et al., 2017);

- aggregates: some studies investigated the reuse of EW for aggregate production (eg. $60-65 \%$ of porphyry quarry dumps can be recovered as high value aggregate for concrete, asphalt concrete and railway ballast; the $25 \%$ for embankment and quarry rehabilitation; and only the 13\% is landfilled: Dino et al., 2017a);

o fines to use in building sector or for land rehabilitation (Careddu and Dino, 2016; Dino et al., 2014; Sivrikaya et al. 2014).

Within the framework of a circular approach, by excavating deposits from EW facilities and recovering CRM and SRM, old "anthropogenic waste deposits" are reintroduced back into material cycles. Meanwhile, land space is liberated and can be reused for new purposes and services such as 
recreational and outdoor activities, industrial or urban redevelopment (including commercial activities), areas for new landfills, or new opportunities to access the primary orebody.

The landfill mining concept starts in the early 1990s and in most of the cases it was limited to extraction of methane, partial recovery of valuable metals and/or land reclamation. Landfill mining strategies are now being further developed with a focus on resource recovery activities of valuable materials either in-situ or ex-situ (Jones et al., 2013). The relevant strategy depends on intrinsic parameters, such as the size, location, age, type, composition and available documentation level of parameters such as availability of suitable technologies and societal and economic boundary conditions (Laner et al., 2016). For instance, industrial waste (including metals, slags, etc.) tend to be more interesting for an ex-situ approach while municipal solid waste is better suited for in-situ approach. In regards to EW facilities, the LFM concept which focus on the recovery of marketable SRM can be summarized in a four-step process as follows: (1) exploration, including site and waste characterisation; (2) mining and transport; (3) processing; and (4) recycling resources/residue disposal (Fig.1).

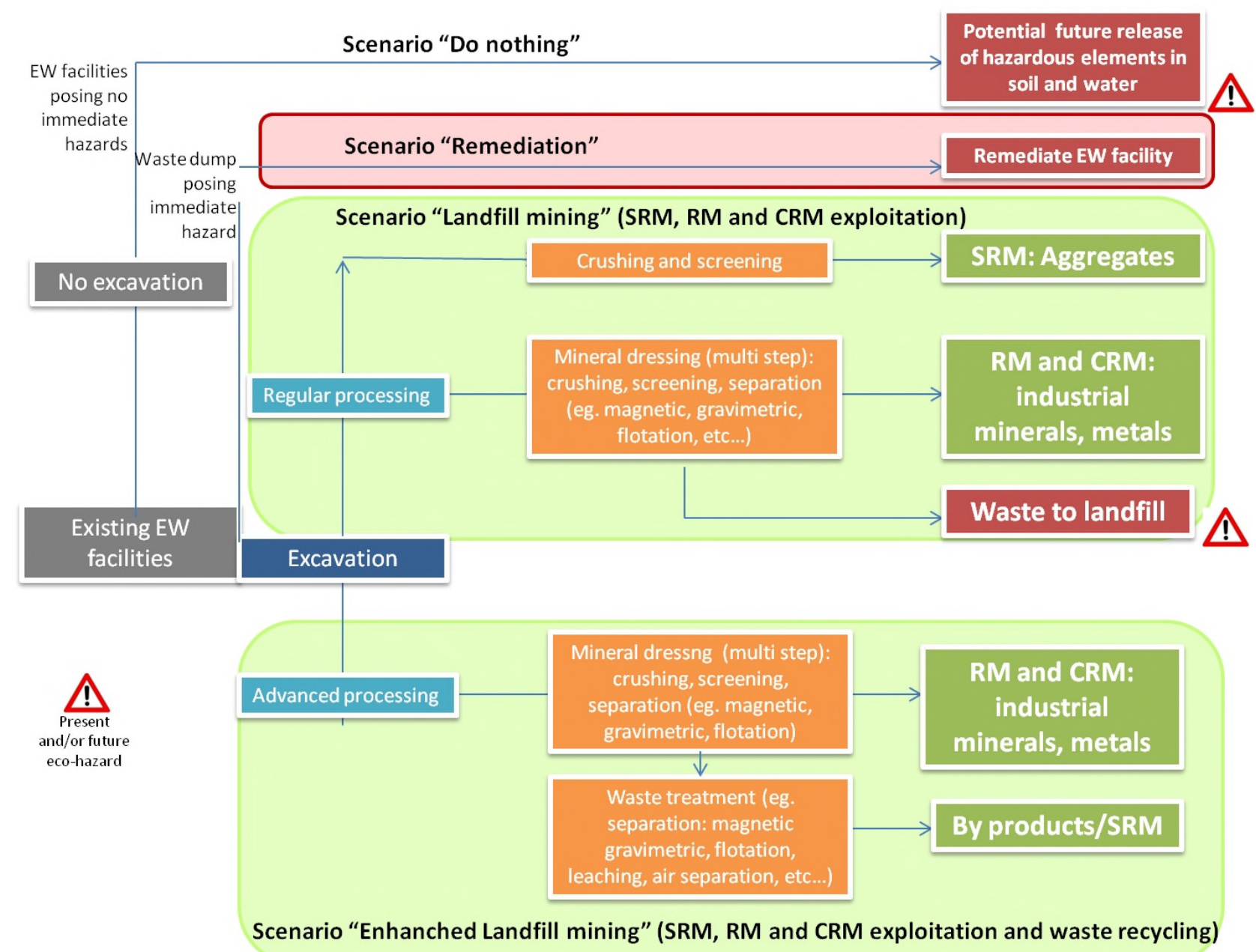

Figure 1. Overview of (Enhanced) LFM Concept, applied at EW

The first scenario considers that the EW deposits are left in place at the facility which may pose in the future potential risks to water and soil (i.e. leaching of hazardous element). The second scenario assumes that remediation occurs at the EW facility in a "more traditional way" (e.g. bioremediation, capping, etc...). The third scenario considers the implementation of LFM strategy where the EW is 
excavated again for the recovery of SRM/CRM. The traditional LFM approach still produces waste which needs to be managed and landfilled, and the potential environmental impacts need to be minimized and mitigated accordingly (eg. impacts on soil and water due to processing and landfilling, impacts on air due to transport and fine particles dispersion; Azam et al., 2007; González-Corrochano et al., 2014; Lim et al., 2009; Helios-Rybicka, 1996; WHO, 2015). The fourth scenario, enhanced LFM (ELFM) considers not only resource recovery of valuable materials but also reuse of waste and by-products. In this scenario, both the mineral dressing of enriched coarse fraction (waste rock and operating residues) and the fine fraction (tailings which still present a profitable content of valuable $\mathrm{RM}$ and/or CRM) are considered as suitable fractions to recover valuable CRM, metals, industrial minerals, etc., and additional waste treatment to produce by products/SRM. For example, the main product from granite waste exploitation is feldspar which is used by the ceramic industry. The associated by-products can be used in building and road construction industries (Bozzola et al., 2010). It is worth to mention that even in this scenario, while not shown on the Fig. 1, there will be environmental impacts that would need to be managed and mitigated (Bellenfant et al., 2013; TirutaBarna et al., 2007). Actually, environmental impacts are still present and connected to dressing activities; these activities produce waste which is different from the mining one (eg. exhaust oils, damaged parts of machineries, dust pumped during the treatment, etc.). Furthermore, water used for treatment has to be properly treated before being recycled or discharged. Such environmental issues are not considered in the present paper, which is focused on methodologies to characterize and evaluate the potential CRM/SRM exploitable from EW facilities.

In the present paper, an integrated framework is proposed to assist the decision making on landfill mining opportunity for EW facilities. The framework describes the key information needed for site and waste characterisation to assess the volume and the amount of potentially recoverable and valuable commodities and its implementation is illustrated through the Gorno $\mathrm{Zn}-\mathrm{Pb}$ mining district case study.

\section{Materials and methods}

\subsection{Case Study}

The Gorno mining district comprises several mining sites distributed over an area of approximately $20 \mathrm{~km}^{2}$. The district is located in the Seriana, Riso and Brembana valleys (Lombardy, Northern Italy) and belongs to the Alpine Type zinc-lead-silver strata bound ore deposits (sub-type of the Mississippi Valley Type deposits), associated with the middle Triassic carbonatic series (Fig. 2). The mineralization of $\mathrm{Zn}-\mathrm{Pb} \pm \mathrm{Ag} \pm$ baryte \pm fluorite deposits mostly occurs within the "Metallifero" (i.e., "ore-bearing") which formed the upper Ladinic - lower Carnian age. The main ore bodies of the district are found in the North-South strait, as tabular "columns" up to $2 \mathrm{~km}$ long, with a width ranging between 50 and $400 \mathrm{~m}$ and a thickness ranging between 3 and $20 \mathrm{~m}$ (Assereto et al. 1977; Omenetto and Vailati 1977; Rodeghiero and Vailati, 1978).

The primary mineralization is mainly composed of sphalerite $(\mathrm{ZnS})$ and galena $(\mathrm{PbS})($ average $\mathrm{Zn} / \mathrm{Pb}$ ratio= 5:1), and minor pyrite $\left(\mathrm{FeS}_{2}\right)$, marcasite $\left(\mathrm{FeS}_{2}\right)$, chalcopyrite $\left(\mathrm{CuFeS}_{2}\right)$ and argentite $\left(\mathrm{Ag}_{2} \mathrm{~S}\right)$. The secondary mineralization, which historically has been preferred, is composed of oxidation products of sphalerite, i.e., Zn-rich carbonate and silicate. The dominant gangue minerals are calcite, dolomite and quartz ( \pm ankerite). 


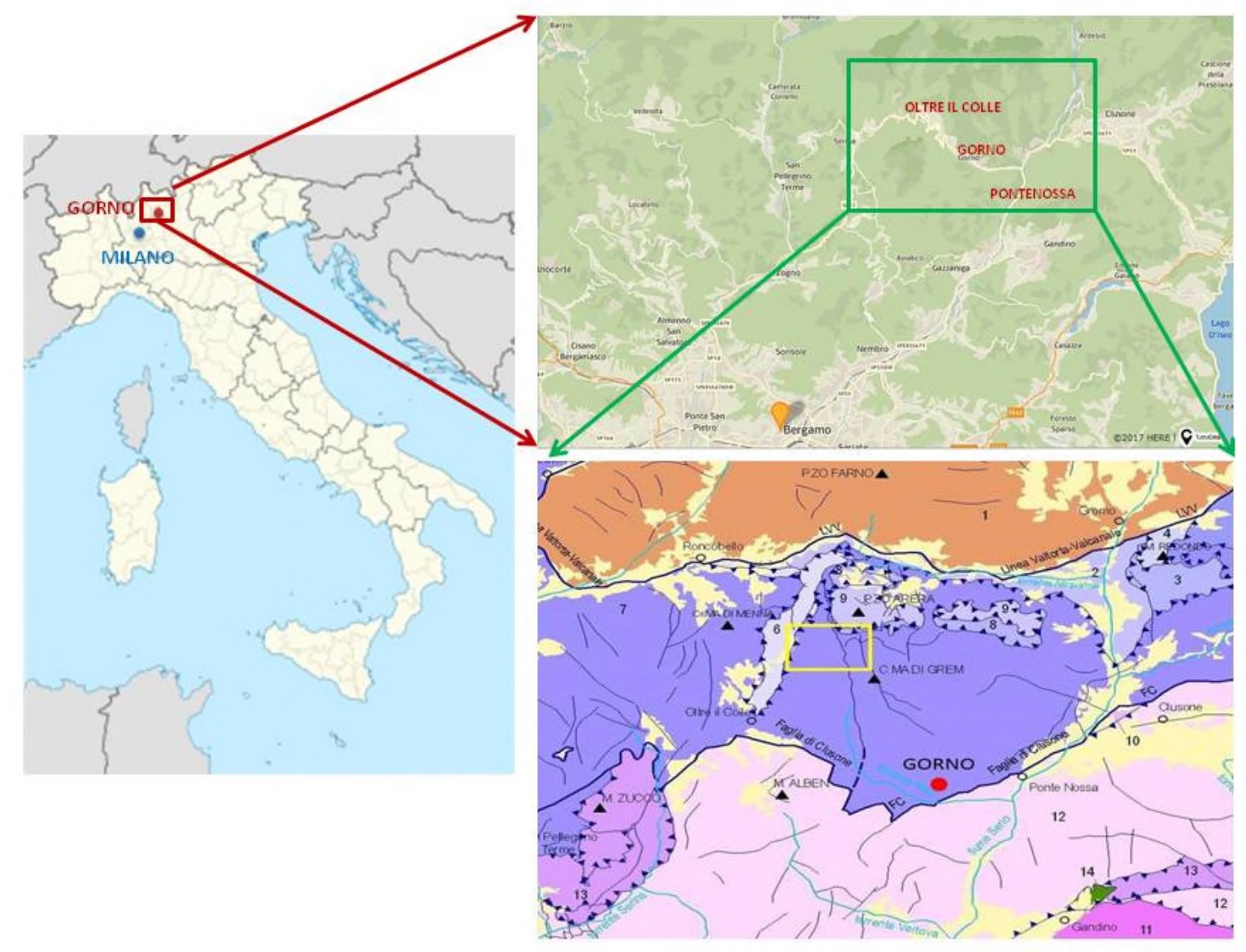

Figure 2. Location (left and upper right) and tectonic sketch-map (lower right) of the Gorno District (Jadoul et al., 2012). The Triassic sedimentary sequence (pink to purple colours) has been partially dismembered into a series of structural units, which overly the basement (orange). The mineralizations occur within the "intermediate structural units" (dark purple in colour). Light yellow areas are Quaternary deposits. The yellow rectangle shows the location of the Arera mining area (see text).

Gorno mining sites were known from Roman period, and probably $\mathrm{Zn}$ exploitation from calamine continued during Medieval age up to the $20^{\text {th }}$ century. The most productive period was from 1882 to 1982, when mining activity represented the main industrial sector in the area, guaranteeing a total production of $0.8 \mathrm{Mt}$ of mineral. Up to 1952 (when Ponte Nossa dressing plant for electrolytic recovery of $\mathrm{Zn}$ was built), the exploited mineral (generally calamine) was manually sorted in the yard outside the mine adits by local people (mostly woman called "taissine"). The raw sorted material, before treatment, had an average content of $\mathrm{Zn}$ of $10 \mathrm{wt} \%$. After treatment, $\mathrm{Zn}$ concentration could read $>50 \% \mathrm{wt} \%$. The enriched ore was then sent to three dressing plants (either Oneta, Val ParinaPlassa or Riso) and finally shipped to England for the final processing.

After the construction of the Ponte Nossa plant, the enriched ore was dressed directly in the factory to obtain $\mathrm{Zn}$ and by-products such as sulfuric acid, $\mathrm{Zn}$ salt, $\mathrm{Cu}$ salt, $\mathrm{Cd}, \mathrm{ZnOx}$. Ponte Nossa plant treated also the minerals from other mining districts (eg. Val Ridanna and Sardinia). The primary dressing plant (laveria) is now closed and only some ruins remain today as traces of past activities. On the contrary, Ponte Nossa treatment plant is still active.

Several traces of past mining activities are evidenced by the presence of waste rock dumps and EW facilities across the district. Among them, the Arera facility is one of the most important which is 
used as case study in this study (6 waste rocks dumps). The other EW facility object of the present study is the tailings basin present in Gorno municipality.

\subsection{Site characterisation framework}

An overview of the standardized characterisation framework developed for EW facilities investigation is provided in Fig. 3. The framework was tested and validated against 10 pilot sites including $6 \mathrm{EW}$ facilities and 4 comingled urban waste landfill sites (Dino et al., 2016). In the present study, the Gorno EW site was selected as a representative case study. The framework comprises 4 phases as follows:

Phase 1: site investigation. After a preliminary investigation, with limited sampling and analytical work to assess the suitability of the site, detailed sampling was performed. In order to adopt a sampling strategy suitable to obtain representative data of the whole waste facility, the following sampling protocol was adopted (Fig. 3):

1. Top layers of the facility, including cover materials and soil, are discarded;

2. Sampling was performed using hand shovel and a hammer for Arera dumping area. Each sampling spot covers an area of approximately of $4 \mathrm{~m}^{2}$. Sampling of tailings was instead performed by hand drilling;

3. The collected coarse material (for waste rock) was screened at $2 \mathrm{~mm}$ and quartered to obtain representative sub-samples for laboratory characterisation. Tailings have been sampled collecting one sample every $50 \mathrm{~cm}$ was taken and the corresponding depth was recorded. Each sample (for tailings) and sub-samples (for waste rock) is saved in bags and each info about sampling point and waste characteristics (size, weight, colour) is reported on a proper form;

4. Sub-samples were taken to laboratory (see also Fig. 4) for characterisation phase to estimate the CRM/SRM content in fine and coarse fractions and to evaluate the environmental impacts mainly connected to fine fractions. 


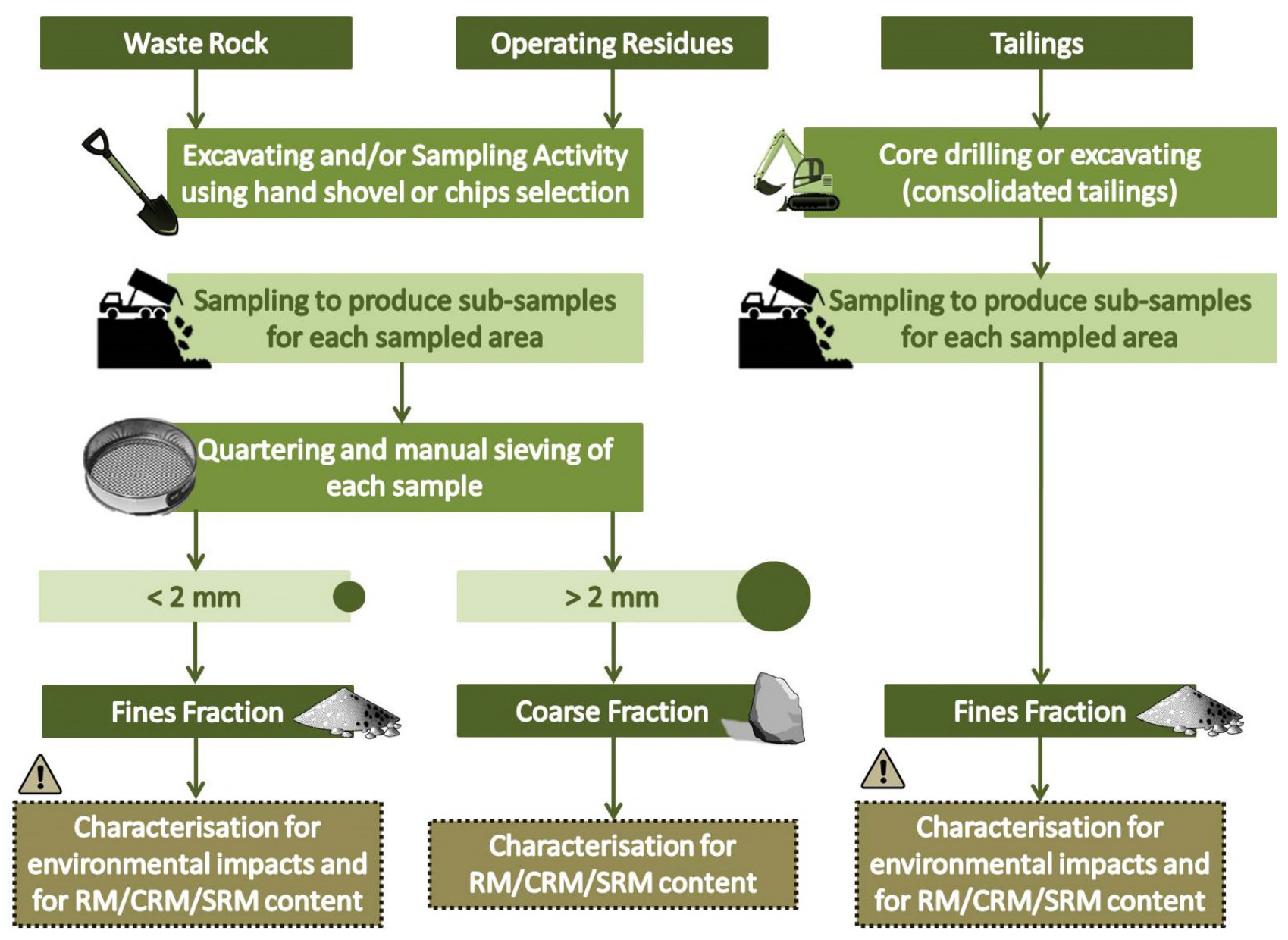

Figure 3. Site Investigation Overview

Phase 2: waste samples characterisation. The overview of the sample characterisation is shown in Fig. 4. All samples need to be processed in order to obtain representative sub-samples for subsequent analyses. For each sampling point, a master sample was stored for any occurrence. At least 5 subsamples have been produced as follows:

- sample as such for physical characterisation;

- sample as such for geochemical characterisation;

- $\quad$ sub-sample $>2 \mathrm{~mm}$ for geochemical characterisation;

- $\quad$ sub-sample $<2 \mathrm{~mm}$ for geochemical characterisation;

- sub-sample $<2 \mathrm{~mm}$ for environmental analysis (not described in the present paper).

Mineralogical and petrographic analyses of the sub-samples were then carried out using optical microscopy and Scanning Electron Microscopy. In particular, the waste rock was characterized by optical transmitted/reflected Polarized Light Microscopy (PLM) on thin/polished (usually $\sim 30 \mu \mathrm{m}$ thick) sections, while the very fine-grained tailings required the adoption of Electron Microscopy (EM) technique. 


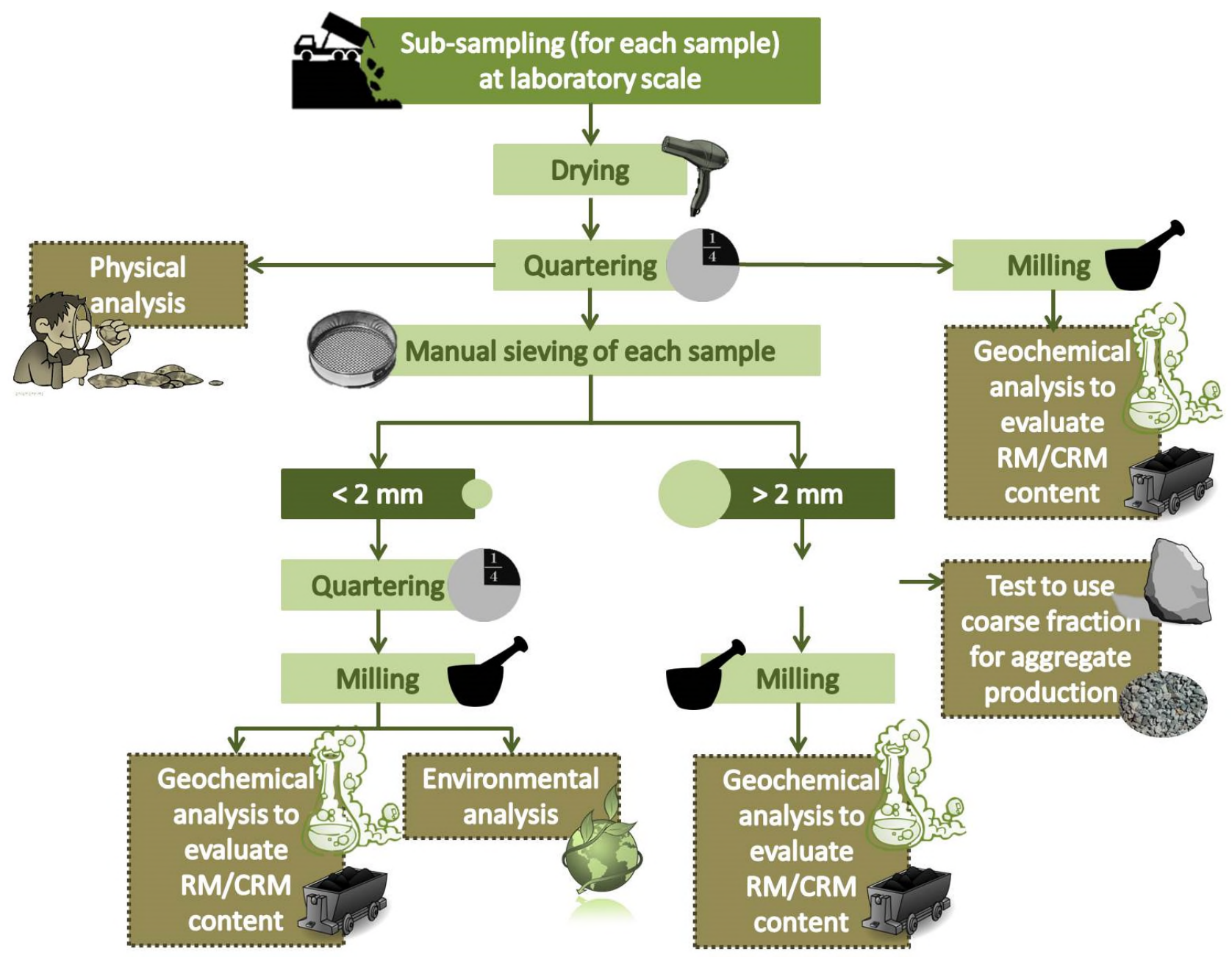

Figure 4. Laboratory procedures overview.

The geochemical analyses were carried out by the ActLabs (Canada). The multi-elements analysis was carried out by total digestion followed by inductively coupled plasma optical emission and mass spectrometry (ICP-OES and ICP-MS, Actlabs code: Ultratrace 6) on all samples (29 samples of waste rock and 18 samples of tailings). The concentration of fluorine was determined using Fusion Specific Ion Electrode (FSIE) method (Actlabs code: 4F-F). 6 waste rock samples with a $\mathrm{Hg}$ concentration exceeding the upper limit for ICP-OES $(10,000 \mathrm{ppb})$ were also analyzed by cold vapour Flow Injection Mercury System (FIMS) (Actlabs code: 1G).

Phase 3: Site Survey and GIS data collection to calculate volume and area. This phase consisted of topographic and morphologic 3D characterisation of the site in order to obtain a GIS detailed reconstruction of the topographic surfaces that will assist the site modeling. Following the preliminary site inspection and analysis, the most suitable survey method was chosen. In general, within the SMART GROUND project activities, most of the topographic surveys on the field have been carried out by means of aerial photogrammetric techniques with differences only in the operating methods (helicopter or UAV) depending on site conditions. Remote sensing techniques and Terrestrial Laser Scanner (TLS) were also used. The choice of operating methods was dependent on area assets (e.g. shape, largeness, elevation range). Local and national map data sources were not in a good nominal scale for this site, thus topographic map data were collected using UAV photogrammetry based survey (Fig.5). 
The output of photogrammetry process is typically a map, drawing, measurement, and 3D model. Nowadays, classic aerial photogrammetry is often replaced by Structure from Motion (SfM) techniques, where the camera is mounted on a helicopter or a UAV, and is usually pointed vertically towards the ground. Multiple overlapping photos of the ground are taken as the aircraft flies along a flight path. These images are later processed to obtain, for example, geometric corrected images (orthophotos) and Digital Surface Models (DSM) (Smith et al. 2015). After conducting the field surveys (UAV flight and Ground control point survey), post-processing activities for the data obtained are necessary. The main data processing steps are:

- matching photo survey;

- building the point cloud in a local reference system;

- mesh wrapping and filtering of outliers;

- texturing 3D model and building an orthomosaic;

- model Georeferencing in the chosen cartographic reference system;

- $\quad$ exporting the georeferenced orthomosaic and Digital Elevation Model;

- extracting cross section and contour.

All steps described above were developed in this case through the use of commercial processing softwares (Photoscan by Agisoft; Reconstructor by Gexcel).

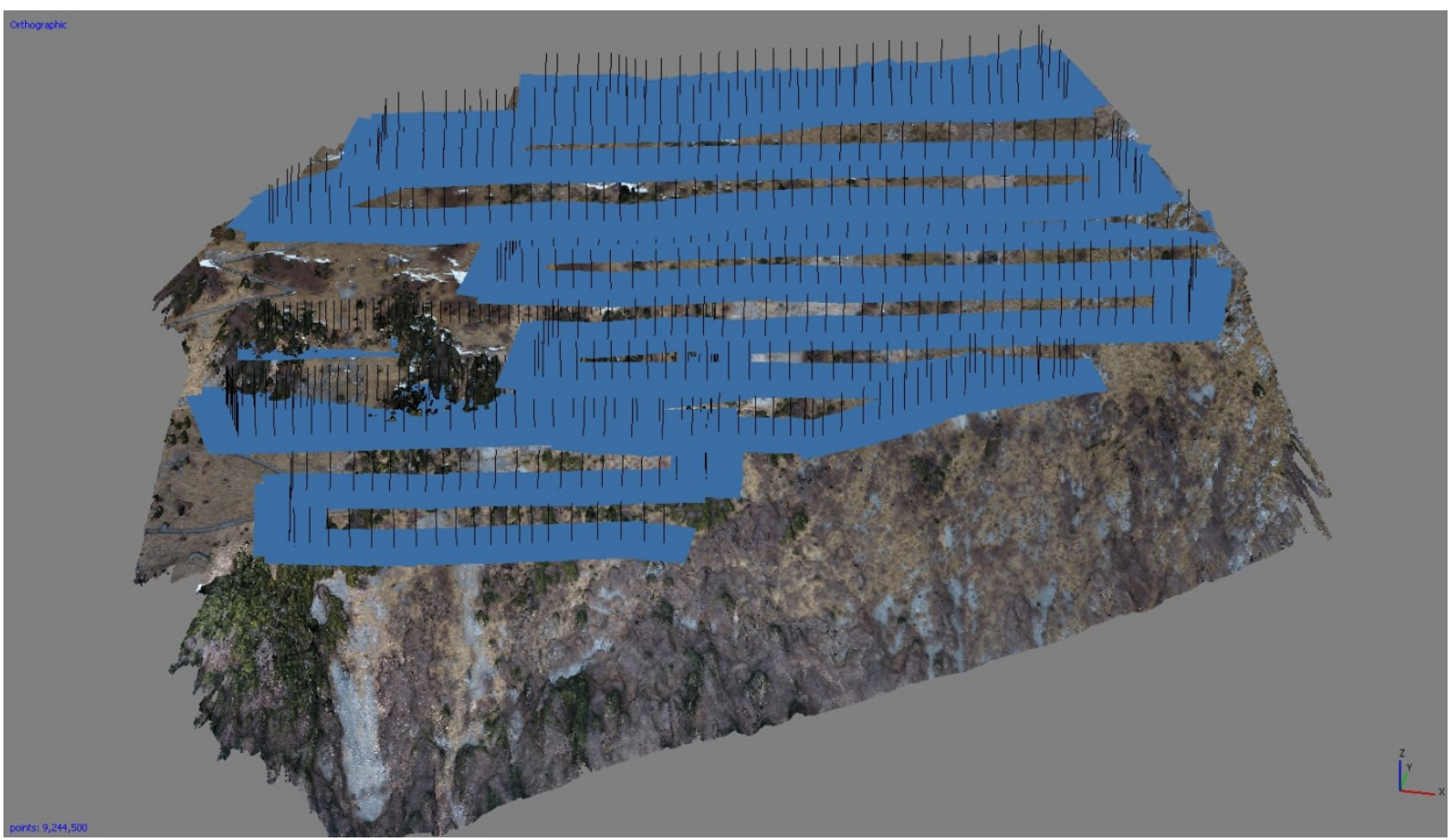

Figure 5. UAV site survey information and textured 3D model and photogrammetric flights camera path.

The outputs information (Fig. 6) was then integrated in a GIS project in order to calculate the volume of the EW. 


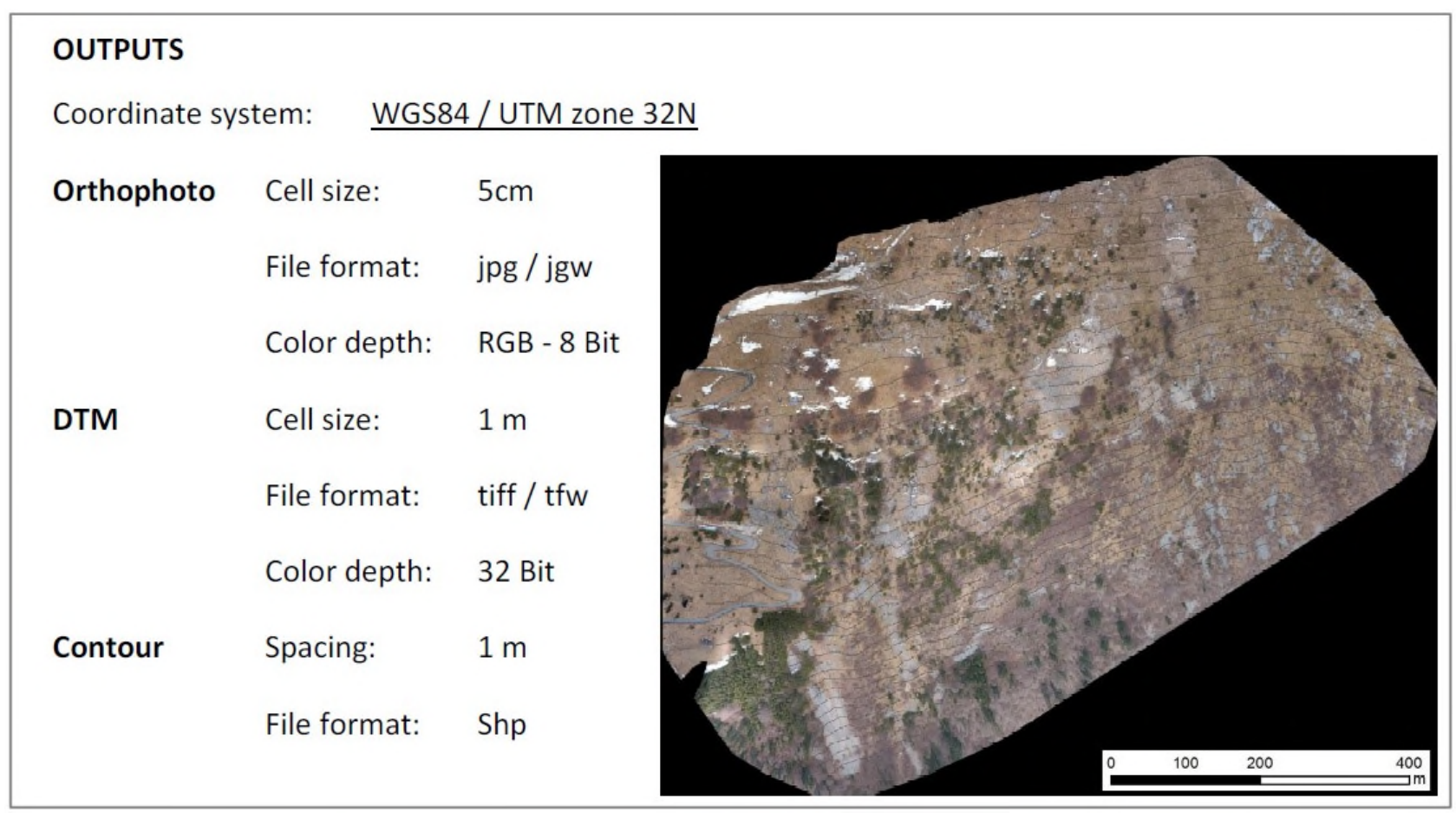

Figure 6. UAV site survey SfM outputs.

\section{Phase 4: Estimation of the residual amounts of recoverable and valuable commodities.}

The amount of commodity in the waste is theoretical due to the fact that, concerning metals, only those occurring within ore minerals may represent exploitable RM/CRM: mineralogical and petrographic analysis are therefore needed to evaluate the real chance to exploit the "new ore body".

For the Gorno mining site, the following resource classification criterion was adopted:

"Indicated resources" are calculated based on waste deposits sampled in detail during the characterisation study;

"Inferred resources" are calculated including also waste deposits whose characters were observed in the field, but that were not sampled and analysed. For them, resource estimates (always conservative) were made based on metals content of the nearest sampled dump and geological considerations.

To determine the residual amounts of materials (as indicated and inferred resource) of a selected commodity (X) the formulas (1) and (2) have been applied.

$$
\begin{aligned}
(1) R i(X) & =V i \times \rho \times G \\
(2) R i i(X) & =V i i \times \rho \times G
\end{aligned}
$$

Where: $R i(X)=$ Indicated resource of commodity X; Rii $(X)=$ Inferred resource of commodity X; $V_{i}$ $=$ volume of the $\mathrm{EW}$ (waste deposits sampled in detail during the characterisation study); $V_{i i}=$ volume of the EW (including also waste deposits whose characters were observed in the field, but that were not sampled and analysed); $\rho=$ average bulk density of the EW; $G=$ average grade of the commodity $\mathrm{X}$ arising from geochemical analysis. 
To determine the theoretical economic value of the remains (indicated and inferred resource), the formulas (3) and (4) have been applied.

$$
\begin{gathered}
\text { (3) } C i(X)=R i \times €(X) \\
\text { (43)Cii }(X)=R i i \times €(X)
\end{gathered}
$$

where: $C i(X)=$ economic value for indicated resource; Cii $(X)=$ economic value for inferred resource; $R i(X)=$ Indicated resource connected to commodity $\mathrm{X} ; \operatorname{Rii}(X)=$ Inferred resource connected to commodity $\mathrm{X} ; €(\mathrm{X})=$ market value for commodity $\mathrm{X}$.

\section{Results and discussion}

\subsection{Phase 1: site investigation}

There were no previous data available on the SRM potential for the site. As already mentioned, after a preliminary survey, the field activity was focused on two areas: (1) Arera mining area (waste rock facilities) and (2) Gorno tailings deposit.

The waste rock sampling activity in the Arera area was focused on six EW facilities (waste rock dumps), in an area of approximately $0,5 \mathrm{~km}^{2}$ (Fig. 7), at the exit of main adits.

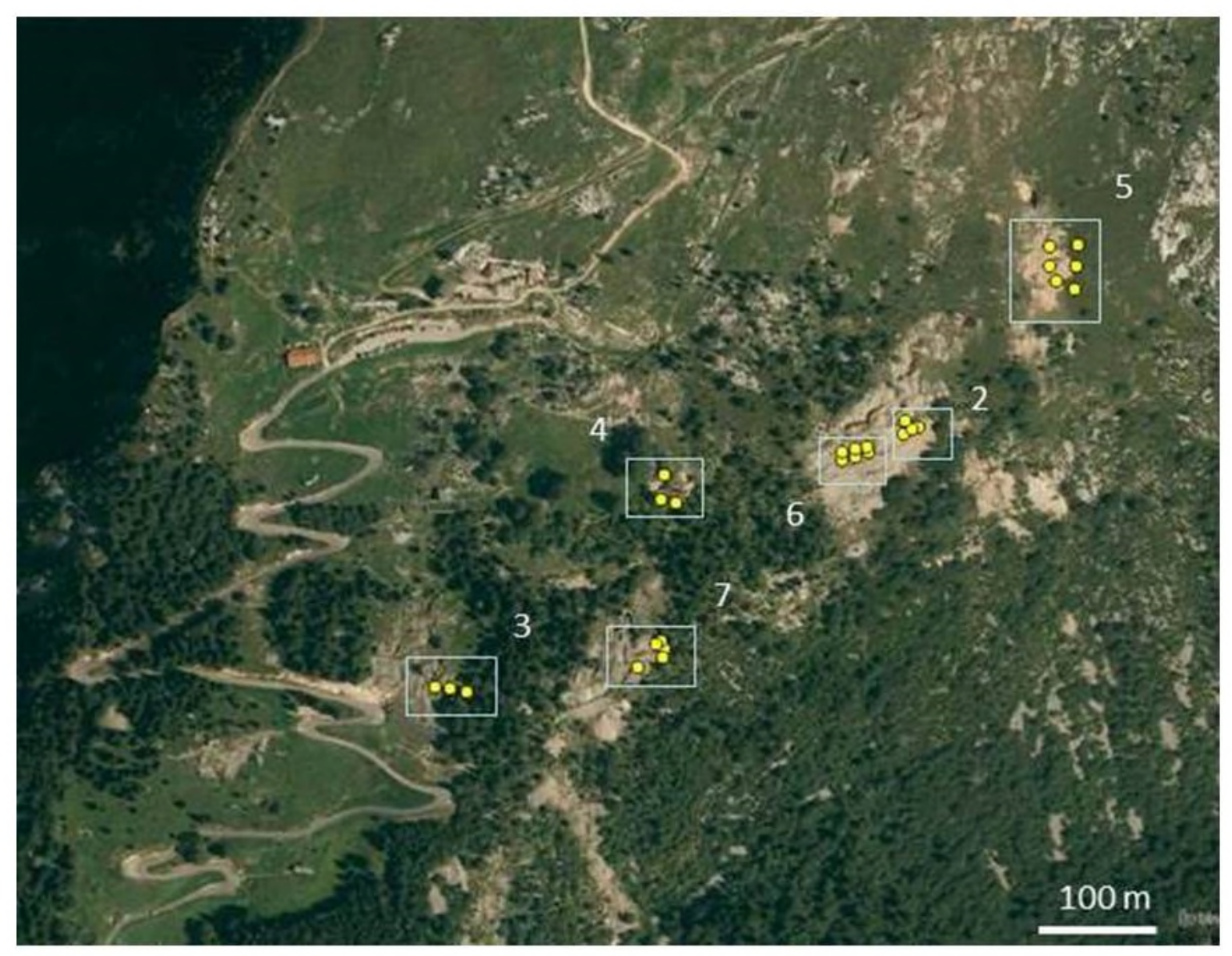

Figure 7. Location of the waste rock sampling points (yellow) in areas 2 to 7. 
Tailing sampling was focused on one tailings deposit in the Gorno mining district, close to the Riso river (Fig. 8). Four sampling points have been identified within the deposit, to check the lateral continuity and the thickness of the top soil: three (DH1, DH2 and DH3) at a distance of 37 meters from each other and the fourth one (DH4) in the easternmost part of the deposit, at a distance of 80 meters from DH3.

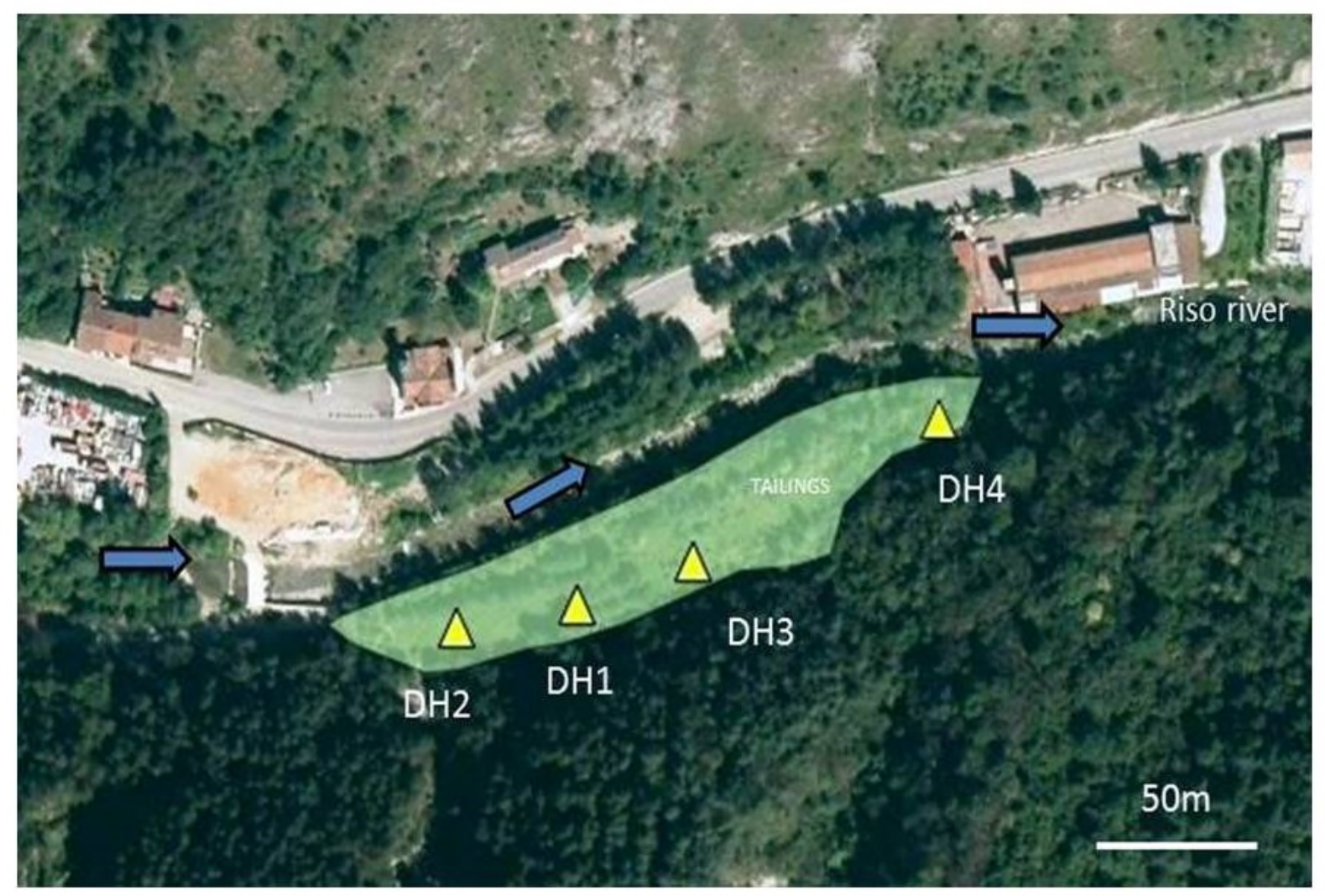

Figure 8. Location of the sampling points in the tailings basin.

\subsection{Mining waste samples characterisation}

\subsubsection{Geochemical characterisation}

The SRM potential of waste materials connected with the alpine-type $\mathrm{Zn}-\mathrm{Pb}$ deposits is represented by $\mathrm{SRM}$ as $\mathrm{Zn}, \mathrm{Pb}, \mathrm{Ag}, \mathrm{Cd}$, and CRM as Ge, Ga, In, fluorite and baryte. The content of $\mathrm{Zn}, \mathrm{Cd}$ and Ga in all samples is shown in Fig. 9.

The key points of the geochemical screening, regarding the potential SRM, are:

- a strong difference is observed between the waste rock samples (areas $2 \div 7$ ) and tailings (area 1), especially for some metals. In particular, tailings are strongly depleted of $\mathrm{Zn}$, but also $\mathrm{Cd}$ and $\mathrm{Ga}$; they are instead enriched in $\mathrm{Pb}$. Ag appears slightly depleted, but the small difference (coupled with the low concentration) is less significant;

- the waste rock is characterized by:

○ strong to very strong $\mathrm{Zn}$ concentration ( 0.65 to $19.30 \mathrm{wt} . \% \mathrm{Zn})$;

○ relatively high $\mathrm{Cd}$ content (22 - $544 \mathrm{ppm})$, and low to moderate Ga values $(2-28$ ppm);

$\bigcirc$ very low Ge and In content (mostly $<1$ ppm, not shown in Fig. 9);

$\circ$ low $\mathrm{Pb}$ and $\mathrm{Ag}$ content (not shown in Fig. 9). 
- the tailings show instead:

○ much lower Zn $(190-8950$ ppm $), \mathrm{Cd}(1.1-39.1 \mathrm{ppm})$ and $\mathrm{Ga}(<0.1-7.0 \mathrm{ppm})$ contents;

$\circ \quad \mathrm{a} \mathrm{Pb}$ content much higher than the waste rocks, but rather low as absolute values (38.7 $-2170 \mathrm{ppm})$.

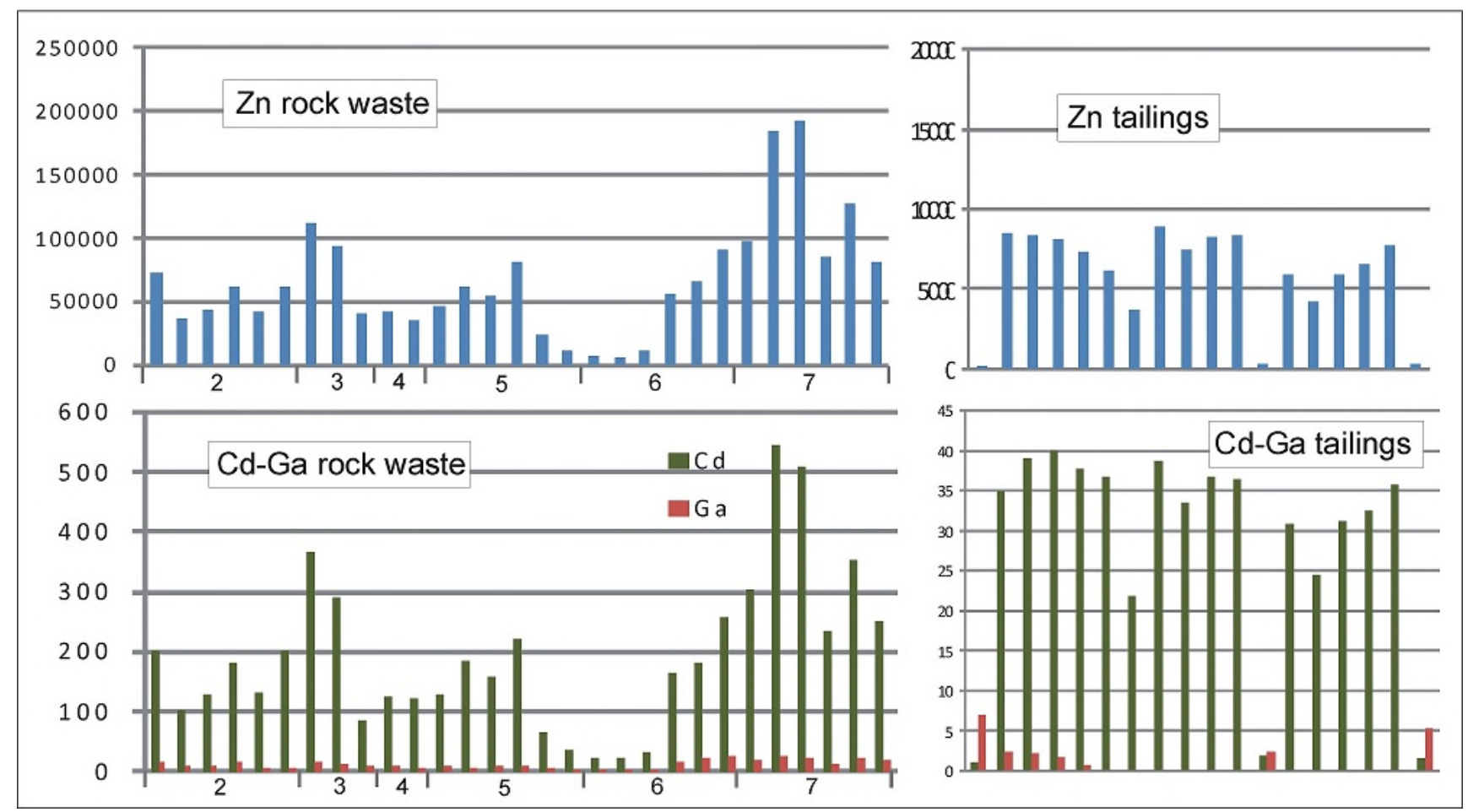

Figure 9. Zn (blue), $\mathrm{Cd}$ (green) and Ga (orange) content in waste rock (left) and tailings samples (right) (values in ppm). The numbers at the base of the diagrams are referred to the different sample areas for waste rock.

Regarding the fluorite and baryte (industrial minerals), their relative abundance can be inferred by the $\mathrm{F}$ and $\mathrm{Ba}$ analyses. As shown in Fig. 10 the fluorine content is moderately high $(0.01-0.12 \mathrm{wt} . \%)$ and no fractionation between waste rock and tailings is observed. Conversely, the barium content is low in the waste rock $(4-101 \mathrm{ppm})$ and much higher in the tailings $(138-2850 \mathrm{ppm})$. 


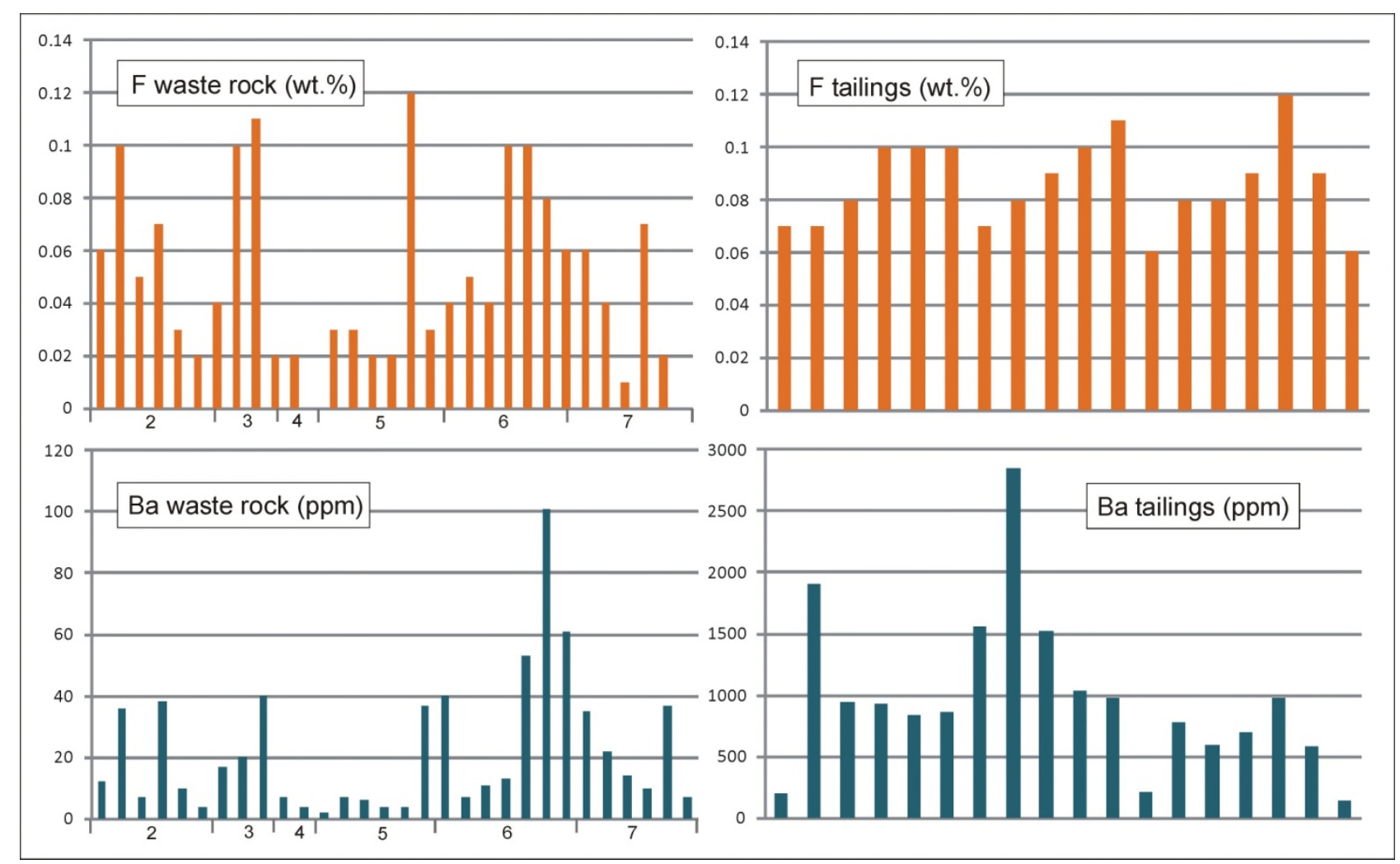

Figure 10. F and $\mathrm{Ba}$ distribution in waste rock and tailing samples.

\subsubsection{Mineralogical and petrographic characterisation}

As aforementioned, 2 types of mineralization occur in the Gorno District, which are both found in the waste rock: primary (i.e., sulphide) ore, and secondary (i.e., oxide) ore.

Under the optical microscope, the waste rocks (mostly dolomitized limestones) are composed of carbonate (dolomite and calcite) and very minor quartz and mica. The primary zinc mineralization is mainly given by the sphalerite, as coarse-grained crystals (up to $1 \mathrm{~cm}$ across) occurring along hydrothermal veins crosscutting the carbonate rocks. Sphalerite is generally the only sulfide, locally associated with very minor pyrite and/or galena (Fig. 11). Scanty grains of fluorite and baryte may also occur. The geochemical analysis of a sphalerite separate shows that sphalerite is almost devoid of iron, but shows a significant Cd content (1970 ppm).

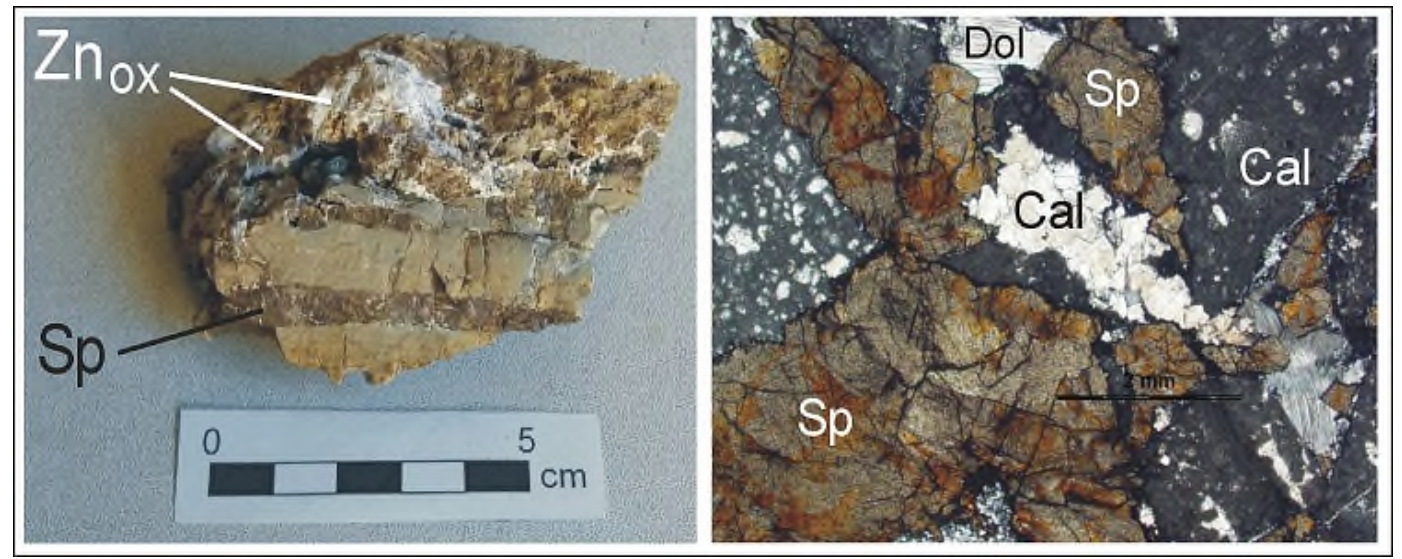

Figure 11. Macro- and microphoto of the zinc mineralization in the waste rock. Left: waste sample showing both the primary (sphalerite, Sp) and the secondary, oxidized ore (Znox). Right: primary mineralization under the optical microscope (transmitted light). The rock is an intergrowth mainly 
composed of calcite (Cal, both as very fine grained matrix and clear bigger crystals), dolomite (Dol) and sphalerite (Sp).

The secondary ore ("calamine") is typically composed of very fine-grained intergrowths of $\mathrm{Zn}$ carbonate (smithsonite, $\mathrm{ZnCO}_{3}$, and/or hydrozincite, $\mathrm{Zn}_{5}\left(\mathrm{CO}_{3}\right)_{2}(\mathrm{OH})_{6}$ ) and hemimorphite, $\mathrm{Zn}_{4}\left(\mathrm{Si}_{2} \mathrm{O}_{7}\right)(\mathrm{OH})_{2} \cdot \mathrm{H}_{2} \mathrm{O}$. The oxidized ore can be locally seen in the waste dumps, as very fine-grained whitish to orange crusts (Fig. 11).

Overall, the primary ore is the dominant ore type in the dumps, however oxide ore may also occur. A rough estimate of the relative proportions of sphalerite and oxide can be calculated from the geochemical analyses, considering that sphalerite is virtually the only sulfide phase. The calculations suggest that in the waste rock, most of the zinc is contained in sphalerite, even if some zinc "oxides" also occur and are dominant in a few samples.

For the tailings, the electron microscopy study shows that:

- the waste material is very fine-grained, and single grains size ranges from $<1 \mu \mathrm{m}$ to ca. 50 $\mu \mathrm{m}$;

- the material is composed of chemically strongly different component (minerals), as shown by differences of brightness (which, in the backscattered images of Fig. 12, is directly proportional to the average atomic weight);

- the in situ chemical analyses allow the recognition of the following minerals: calcite, dolomite, micaceous/clay material, quartz, baryte, Fe sulphate, Zn-silicate (hemimorphite), $\mathrm{Zn}$-carbonate (smithsonite and/or hydrozincite) and rare $\mathrm{Cu}-\mathrm{As}-\mathrm{Sb} \pm \mathrm{Pb}$ sulphosalt(s) (these latters too fine grained for an even semi-quantitative analysis).
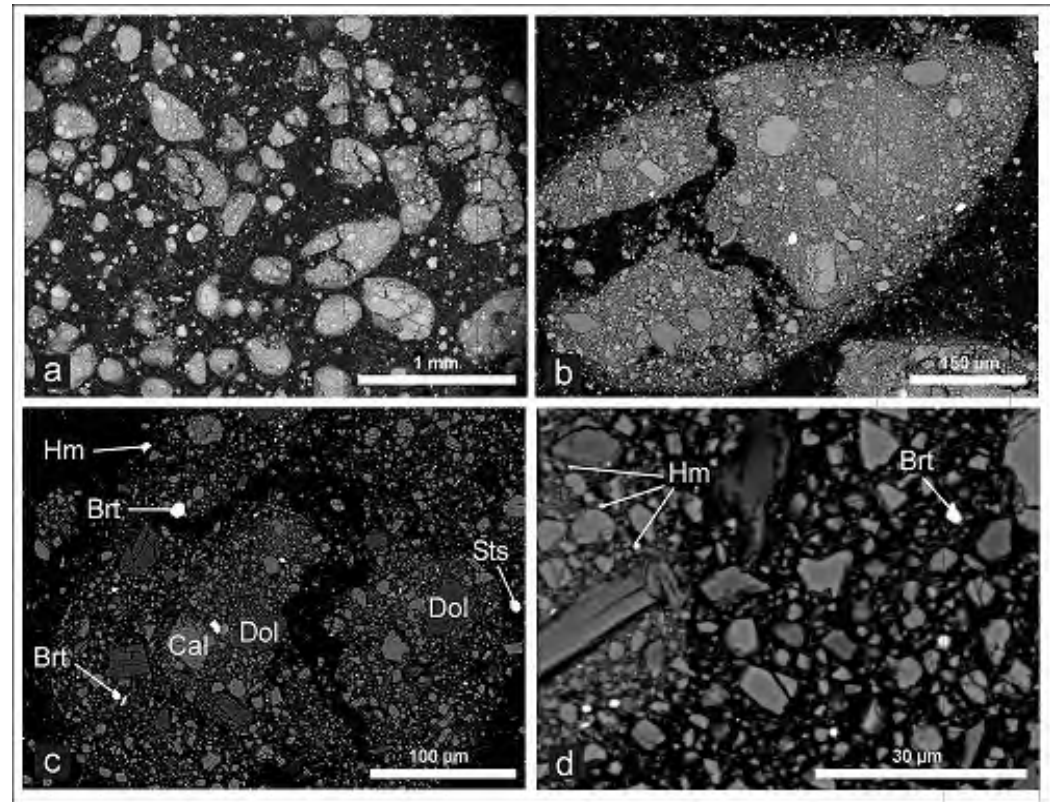

Figure 12 Electron microscope backscattered images of the tailings at increasing magnification, from a) to d). Cal: calcite, Brt: baryte, Dol: dolomite, Hm: hemimorphite, Sts: smithsonite.

Concerning the possible CRM/SRM:

- metallic phases are quite rare. Zn mostly occurs as very fine-grained "oxide" minerals, both as silicate (hemimorphite, containing ca. $67 \mathrm{wt} \% \mathrm{ZnO}$ ) and carbonate (smithsonite and/or hydrozincite, containing ca. 65 and 74 wt.\% ZnO, respectively) (Fig. 12); 
- $\quad$ extremely fine grained baryte (BaSO4) has often been detected (Fig. 12).

\subsection{Volume and areas calculation}

The new digital data (from phase 3) facilitated advanced GIS project site capabilities, through topographic data extraction (2D-3D measurements) and 3D modelling functions. The new high resolution digital orthophotos and DSMs allowed the detection and the detailed definition of the dump areas (indicated and/or inferred) (Fig. 13). Furthermore, 3D volume estimation of the dumps were carried out, by means of estimating the average thickness for each EW area polygon in order to obtain a volume calculation. Accuracy in area and volume estimation was dependent on the accuracy of the carthographic orthophoto and DSM accuracy.

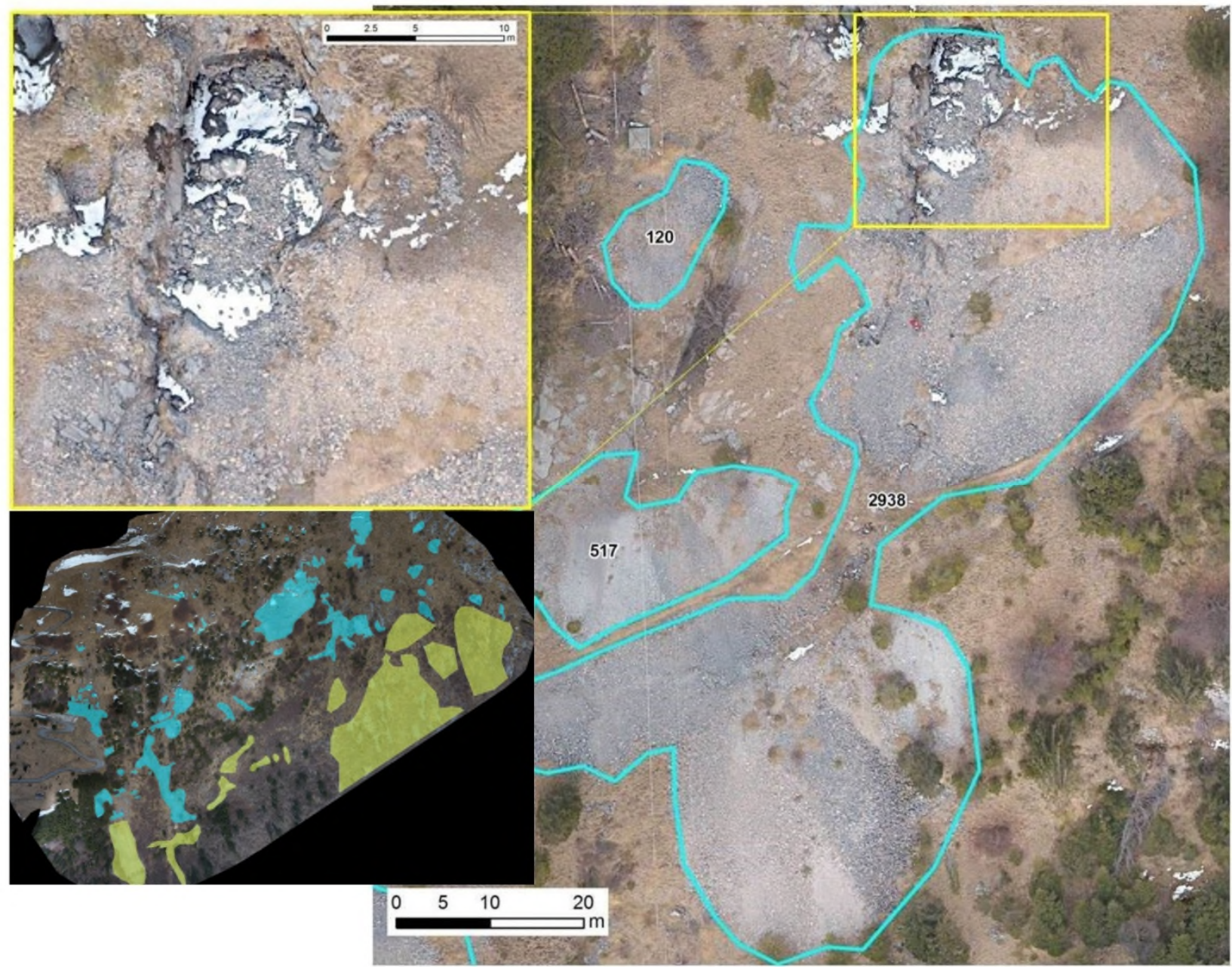

Figure 13. High resolution orthophoto including EW dump polygons. Light blue polygons indicate area values. Upper left - Particular of dump site visualization on high resolution orthophotos $(3 \mathrm{~cm})$.

Final volume calculation are presented in Table. 1. Within the GIS project maps, the projected area of each polygon dump was calculated, with every polygon reduced at real inclination by means of elevation data available. The final volume estimation was calculated with thickness estimation performed for both indicated and inferred dumps.

Table 1. Volume estimation resume 


\begin{tabular}{|cccccc|}
\hline $\begin{array}{c}\text { Dumps } \\
\text { type }\end{array}$ & \# of Dumps & $\begin{array}{c}\text { Total Projected } \\
\text { Area } \\
\mathbf{m}^{\mathbf{2}}\end{array}$ & $\begin{array}{c}\text { Real Surface } \\
\text { Area } \\
\mathbf{m}^{\mathbf{2}}\end{array}$ & $\begin{array}{c}\text { Thickness } \\
\text { Estimation } \\
\mathbf{m}\end{array}$ & $\begin{array}{c}\text { Volume } \\
\text { Estimation } \\
\mathbf{m}^{\mathbf{3}}\end{array}$ \\
\hline Indicated & 6 & 15.162 & 16.957 & 2 & $\mathbf{3 3 . 9 1 4}$ \\
\hline Inferred & 68 & 104.694 & 124.739 & 2 & $\mathbf{2 4 9 . 4 7 7}$ \\
\hline
\end{tabular}

\subsection{Estimation of the recoverable commodities at the site}

The previously described geochemical information from phase 2 (section 3.2), associated with the volume calculation from phase 3 (section 3.3), were used as input data for the mineral resource estimation.

To evaluate the commodity quantity in waste rock (Table. 2) we used:

- the $\mathrm{Zn}, \mathrm{Cd}, \mathrm{Ga}$ average content arising from the geochemical analysis on waste rock samples;

- the volume estimated for each area (both for indicated resources and inferred resources, see below);

- the bulk density calculate for waste rocks $\left(1334 \mathrm{~kg} / \mathrm{m}^{3}\right.$ in average).

Table 2. Content of commodities from Gorno mine waste rock

\begin{tabular}{|c|c|c|c|c|}
\hline $\begin{array}{l}\text { Resource } \\
\text { Type }\end{array}$ & volume $\&$ mass & Commodity & $\begin{array}{c}\text { Commodity mass } \\
{[\mathrm{kg}]}\end{array}$ & $\begin{array}{l}\text { Commodity in- } \\
\text { situ value }[€]^{*}\end{array}$ \\
\hline \multirow{3}{*}{$\begin{array}{l}\text { Indicated } \\
\text { resources }\end{array}$} & \multirow{3}{*}{$\begin{array}{r}\text { volume } 33.914 \mathrm{~m}^{3} \\
\text { mass } 45.105 \mathrm{t}\end{array}$} & $\mathrm{Zn}$ & 5.271 .000 & 13.388 .757 \\
\hline & & $\mathrm{Cd}$ & 15.416 & 18.654 \\
\hline & & $\mathrm{Ga}$ & 1.125 & 132.754 \\
\hline \multirow{3}{*}{$\begin{array}{c}\text { Inferred } \\
\text { resources }\end{array}$} & \multirow{3}{*}{$\begin{array}{r}\text { volume } 249.477 \\
\mathrm{~m}^{3} \\
\text { mass } 330.886 \mathrm{t}\end{array}$} & $\mathrm{Zn}$ & 24.766 .000 & 62.912 .767 \\
\hline & & $\mathrm{Cd}$ & 73.043 & 88.382 \\
\hline & & $\mathrm{Ga}$ & 4.479 & 528.572 \\
\hline
\end{tabular}

* Values from www.snl.com and https://minerals.usgs.gov/minerals/pubs/.

It has to be reminded that resource estimates (always conservative) were made based on metals content of the nearest sampled dump and geological considerations. In detail, "Indicated resources" were calculated based on waste deposits which were sampled in detail during the characterization study, while "Inferred resources" include also waste deposits whose characters were observed in the field, but that were not sampled and analysed.

To evaluate the commodity quantity in the tailing deposits (Table. 3) we used:

- the baryte and $\mathrm{Pb}$ average content arising from the geochemical analysis on tailings samples. In particular, the baryte content was calculated from the Ba value given by the geochemical analyses;

- the volume estimated for each area (both for indicated resources and inferred resources);

- the bulk density calculated for tailings $\left(1810 \mathrm{~kg} / \mathrm{m}^{3}\right.$ in average $)$.

It is important to highlight that the commodity value, as for baryte, is quite variable. Therefore we took a conservative approach by using the lowest cost value. As for tailing resources, no diagram was produced due to the variability of baryte values.

Table 3. Content of commodities from Gorno tailings 


\begin{tabular}{|lllrr|}
\hline $\begin{array}{c}\text { Resource } \\
\text { Type }\end{array}$ & volume \& mass & \multicolumn{1}{c}{ Commodity } & $\begin{array}{c}\text { Commodity mass } \\
\text { [kg] }\end{array}$ & $\begin{array}{c}\text { Commodity in- } \\
\text { situ value [€] }\end{array}$ \\
\hline $\begin{array}{l}\text { Indicated } \\
\text { resources }\end{array}$ & $\begin{array}{l}\text { volume } 23.400 \mathrm{~m}^{3} \\
\text { mass } 42.354 \mathrm{t}\end{array}$ & baryte & 24.904 & $\geq 1.992$ \\
\cline { 3 - 5 } & $\mathrm{Pb}$ & 59.931 & 127.773 \\
\hline $\begin{array}{l}\text { Inferred } \\
\text { resources }\end{array}$ & $\begin{array}{l}\text { volume } 53.460 \mathrm{~m}^{3} \\
\text { mass } 96.763 \mathrm{t}\end{array}$ & baryte & 56.896 & $\geq 4.552$ \\
\cline { 3 - 6 } & $\mathrm{Pb}$ & 136.919 & 291.911 \\
\hline
\end{tabular}

* Values from www.snl.com and www.indmin.com.

\section{CONCLUSIONS}

This paper presents the results connected to the site characterisation of EW facilities, focusing on an Italian case study (Gorno mining district).

Italy was, and still is, one of the most important countries for quarrying and (subordinately) mine exploitation, with a consequent huge production of EW. The wastes are stored in EW facilities, which need to be monitored for environmental and health impacts, but which can also be considered as potential new mining areas: EW still contains CRM/SRM not exploited and/or not known during the exploitation phase, which could be recovered as RM/SRM supply.

This study emphasizes the complexity of the SRM estimation in waste deposits connected with the extractive industry, suggesting that a thorough characterization of each waste deposit, following a proper methodology based on a multidisciplinary approach, is a prerequisite for a reliable resource evaluation. The characterisation of EW facilities is fundamental to estimate the recoverable commodities at the site. Following a specific characterisation framework composed of 4 phases as described in section 2, it has been possible to evaluate the potential remains present in Gorno EW facilities (waste rock dumps and tailings deposits) both as indicated and inferred resources (section 3). Metals distribution is non-homogeneous and strong differences occur between waste rock and tailings. The data presented suggest that $\mathrm{Zn}$ and $\mathrm{Cd}$ (and possibly $\mathrm{Ga}$ as $\mathrm{CRM}$ ) can potentially be recovered from the waste rock deposits. These commodities occur well above the typical rock content and within minerals (mainly sphalerite) suitable for metals recovery. Other CRM present in the sphalerite, like Ge and In, are instead extremely low in concentration: after all, the purity of the sphalerite is a typical feature of the Gorno's mineralization when compared to sphalerite from $\mathrm{Zn}-\mathrm{Pb}$ deposits of the Eastern Alps (Dessau, 1967). Tailings are strongly depleted of most metals, only showing moderate enrichments in $\mathrm{Pb}$ and baryte.

The data collected from Gorno pilot site, together with the data and information coming from the characterisation of other 9 pilot sites, have been used to test and validate the site characterisation framework and to populate the Smart Ground platform (SG Platform). The SG platform is intended to provide a reliable and transparent source of harmonized and validated information on SRM estimates from anthropogenic deposits available across Europe (Dino et al., 2017,b). Once the SG platform will be populated with consistent data and information based on the proposed standardized framework of this study, the platform will become a valuable reference point of potential inventory of RM/SRM sources from anthropogenic waste deposits and EW facilities.

\section{ACKNOWLEDGEMENTS}

The authors wish to thank Mr. Fabrizio Scolari, Comune di Gorno, for making available his wide knowledge about Gorno mining site. A special thank to Giorgio Carbotta and Giulio Biglia (Dept. of Earth Sciences - UNITO) for their precious help during field surveys and sampling activities.

\section{FUNDING}


This work is part of SMART GROUND project and has received funding from the European Union's Horizon 2020 research and innovation programme under Grant Agreement No 641988.

\section{REFERENCES}

1. Assereto, R., Jadoul, F., Ometto, P., 1977. Stratigrafia e metallogenesi del settore occidentale del distretto a $\mathrm{Pb}, \mathrm{Zn}$, fluorite e barite di Gorno (Alpi Bergamasche). Rev. Ital. Paleontol. Stratigr. 83, 395-532.

2. Azam, S., Wilson, G.W., Herasymuik, G., Nichol, C., Barbour, L.S., 2007. Hydrogeological behaviour of an unsaturated waste rock pile: a case study at the Golden Sunlight Mine, Montana, USA. Bull. Eng. Geol. Environ. 66, 259-268.

3. Bellenfant, G., Guezennec, A., Bodenan, F., D'Hugues, P., Cassard, P., 2013. Re-processing of mining waste: Combining environmental management and metal recovery? Mine Closure 2013, Sep 2013, Cornwall, United Kingdom. 571-582.

4. Blagoeva, D., Aves Dias, P., Marmier, A., Pavel C., 2016. Assessment of potential bottlenecks along the materials supply chain for the future deployment of low-carbon energy and transport technologies in the EU. Wind power, photovoltaic and electric vehicles technologies, time frame: 2015-2030. European Commission, DG Joint Research Centre. (No. EUR 28192 EN, doi: http://dx.doi.org/10.2790/08169).

5. Blengini, G.A., Nuss, P., Dewulf, J., Nita, V., Talens Peirò, L., Vidal-Legaz, B., Latunussa, C., Mancini L., Blagoeva, B., Pennington, D., Pellegrini, M., Van Maercke, A., Solar, S., Grohol, M., Ciupagea, C., 2017. EU methodology for critical raw materials assessment: Policy needs and proposed solutions for incremental improvements. Resources Policy. 53, $12-19$.

6. Bozzola, G., Dino, G.A., Fornaro, M., Lorenzi, A., 2010. Technological innovations and secondary raw materials obtained from virtuous management of wastes connected to mining activities: The examples of Gruppo Minerali Maffei s.p.a. Rendiconti on line della Società Geologica Italiana. 519-520.

7. BRGM, 2001. Management of mining, quarrying and ore-processing waste in the European Union. Study made for DG Environment, European Commission Co-ordination by P. Charbonnier. December 2001. BRGM/RP-50319-FR. pp. 88

8. Careddu, N., Dino, G.A., 2016. Reuse of residual sludge from stone processing: differences and similarities between sludge coming from carbonate and silicate stones-Italian experiences. Environ Earth Sci. 75:1075. https://doi.org/10.1007/s12665-016-5865-1

9. Coulomb, R., Dietz, S., Godunova, M., Bligaard Nielsen, T., 2015. Critical Minerals Today and in 2030 (OECD Environment Working Papers). Organisation for Economic Cooperation and Development, Paris.

10. Dessau, G., 1967. Gli elementi minori nelle blende e nelle galene della miniera di Salafossa. Confronti con i giacimenti del Bergamasco e di Raibl. Proc. Giornata di Studi Geominerari, Agordo, 123-134. 
11. Dino, G.A., Rossetti, P., Lorenzi, A., Mister, I., Cazzaniga, A., Coulon, F., Griffiths, Z., Wagland, S., 2018. Exploiting secondary raw materials from extractive waste facilities: a case study. In proceedings: $4^{\text {th }}$ International Symposium on Enhanced Landfill Mining. Mechelen, 4-6 February 2018. 75-81.

12. Dino, G.A., Danielsen, S.W., Chiappino, C., Engelsen, C.J., 2017, a.. Recycling of rock materials as part of sustainable aggregate production in Norway and Italy. Quarterly Journal of Engineering Geology and Hydrogeology. 50(4): 412-416.

13. Dino, G.A., Rossetti, P., Biglia, G., Sapino, M.L., Di Mauro, F., Särkkä, H., Coulon, F., Gomes, D., Parejo-Bravo, L., Aranda, P.Z., Lopez, A.L., Lopez, J., Garamvolgy, E., Stojanovic, S., Pizza, A., de la Feld, M., 2017,b. Smart ground project: A new approach to data accessibility and collection for raw materials and secondary raw materials in Europe. Environmental Engineering and Management Journal. 16(8): 1673-1684.

14. Dino, G.A., Rossetti, P., Biglia, G., Coulon, F., Gomes, D., Wagland, S., Luste, S., Särkkä, H., Ver, C., Delafeld, M., 2016. SMART GROUND Project: SMART Data Collection and Integration Platform to Enhance Availability and Accessibility of Data and Information in the EU Territory on Secondary Raw Materials. Energy Procedia. 97, 15-22.

15. Dino, G.A., Passarella, I., Ajmone Marsan, F., 2014. Quarry rehabilitation employing treated residual sludge from dimension stone working plant. Environ. Earth Sci. 73 (11), 7157-7164.

16. EC, 2017. Study on the review of the list of Critical Raw Materials. Executive summary. Brussels, Belgium, 9 pp.

17. Edraki, M., Baumgartl, T., Manlapig, E., Bradshaw, D., Franks, D.M., Moran C.J., 2014. Designing mine tailings for better environmental, social and economic outcomes: a review of alternative approaches. J. Clean. Pro. 84, 411-420.

18. Eurostat, 2017. Waste statistics for European Commission, Online at: http://ec.europa.eu/eurostat/statistics-explained/index.php/Waste statistics

19. Finnvedenlz, G., Albertsson, A.-C., Berendson, J., Eriksson, E., Olof Höglund, L., Karlsson, S., Sundqvist, J.-O., 1995. Solid waste treatment within the framework of life-cycle assessment. J. Clean. Prod. 3 (4), 189-199.

20. González-Corrochano, B.; Esbrí, J.M.; Alonso-Azcárate, J.; Martínez-Coronado, A.; Jurado, V.; Higueras, P., 2014. Environmental geochemistry of a highly polluted area: The La Union $\mathrm{Pb}-\mathrm{Zn}$ mine (Castilla-La Mancha region, Spain). J. Geochem. Explor. 144 (B), 345-354.

21. Gordon, R.B., 2002. Production residues in copper technological cycles. Resour. Conserv. Recycl. 36, 87-106.

22. Habib, K., Wenzel, H., 2014. Exploring rare earths supply constraints for the emerging clean energy technologies and the role of recycling. J. Clean. Prod. 84, 349-359. 
23. Jadoul, F., Berra, F., Bini, A., Ferliga, C., Mazzoccolla, D., Papani, L., Piccin, A., Rossi, R., Trombetta, G.L., 2012. Note illustrative della Carta Geologica d'Italia alla scala 1:50.000, Foglio 77-Clusone. ISPRA, Roma. pp. 232.

24. Jones, P. T., Geysen, D., Tielemans, Y., Van Passel, S., Pontikes, Y., Blanpain, B., Quaghebeur, M. and Hoekstra, N. (2013) 'Enhanced Landfill Mining in view of multiple resource recovery: A critical review', Journal of Cleaner Production. 55, pp. 45-55.

25. Laner, D., Cencic, O., Svensson, N. and Krook, J. (2016) 'Quantitative Analysis of Critical Factors for the Climate Impact of Landfill Mining', Environmental Science \& Technology, 50, pp. 6882-6891

26. Lim, M., Han, G.C., Ahn, J.W., You, K.S., Kim, H.S., 2009. Leachability of Arsenic and Heavy Metals from Mine Tailings of Abandoned Metal Mines. Int. J. Environ. Res. Public. Health. 6, 2865-2879.

27. Omenetto, P., Vailati, G., 1977. Ricerche geominerarie nel settore centrale del distretto a PbZn, fluorite e barite di Gorno (Lombardia). L'Industria Mineraria, 28, 25-44.

28. Pavel, C., Tzimas, E., 2016. Raw Materials in the European Defence Industry, EUR 27542 EN. European Commission, DG Joint Research Centre, Petten, Netherlands. http://dx.doi.org/10.2790/0444.

29. Helios-Rybicka, E., 1996. Impact of mining and metallurgical industries on the environment in Poland. Applied Geochemistry. 11; 3-9.

30. Rodeghiero, F., Vailati, G., 1978. Nuove osservazioni sull'assetto geologico-strutturale del settore centrale del distretto piombo-zincifero di Gorno (Alpi Bergamasche). L'Industria Mineraria. 29, 298-302.

31. Rossetti, P., Dino, G.A., Biglia, G., Costa, E., 2017. Characterization of secondary raw materials from mine waste: a case study from the Campello Monti $\mathrm{Ni} \pm \mathrm{Cu} \pm \mathrm{Co} \pm \mathrm{PGE}$ mining site (Western Alps, Italy). Proceedings Sardinia 2017 / Sixteenth International Waste Management and Landfill Symposium/ 2 - 6 October 2017. S. Margherita di Pula, Cagliari, Italy / (C) 2017 by CISA Publisher, Italy. ISSN 2282-0027

32. Sivrikaya, O., Kıyıldı, K.R., Karaca, Z., 2014. Recycling waste from natural stone processing plants to stabilize clayey soil. Environmental Earth Science. 71, 4397-4407

33. Smith, M.V., Carrivick, J.L., Quincey, D.J., 2015. Structure from motion photogrammetry. Physical Geography. 40, 247-275.

34. Tiruta-Barna, L., Benetto, E., Perrodin, Y., 2007. Environmental impact and risk assessment of mineral wastes reuse strategies: Review and critical analysis of approaches and applications. Resour. Conserv. Recycl. 50(4), 351-379.

35. Vidal-Legaz, B., Mancini, L., Blengini, G., Pavel, C., Marmier, A., Blagoeva, D., Latunussa, C., Nuss, P., Dewulf, J., Nita, V., Kayam, Y., Manfredi, S., Magyar, A., Dias, P., Baranzelli, 
C., Tzimas, E., Pennington, D., 2016. EU Raw Materials Scoreboard 1st ed.. Publications Office of the European Union, Luxembourg. G.A.

36. World Health Organization (WHO), 2015. Lead poisoning and health. Fact Sheet

379.Reviewed August 2015.
www.who.int/mediacentre/factsheets/fs379/en/. 